\title{
The Effects of Formalin Solution on Wall Thickness and Size in Stomach Resection Materials
}

\section{Mide Rezeksiyon Materyallerinde Formalin Solüsyonunun Duvar Kalınlığına ve Boyutuna Etkisi}

\author{
Hüseyin Çiyiltepe,' (D) Anıl Ergin,' (1D Adnan Somay,2 (D) Nuriye Esen Bulut,' \\ D Mehmet Mahir Fersahoğlu,' (1) Mehmet Köroğlu, ${ }^{3}$ (D) Aziz Bora Karip,' (1) Ümit Akyüz, ${ }^{3}$ \\ Kemal Memişoğlu'
}

${ }^{1}$ Department of General Surgery, University of Health Sciences, İstanbul Fatih Sultan Mehmet Training and Research

Hospital, İstanbul Turkey

2Department of Pathology, University of Health Sciences, İstanbul Fatih Sultan Mehmet Training and Research

Hospital, İstanbul Turkey ${ }^{3}$ Department of Gastroenter-

ology, University of Health Sciences, İstanbul Fatih Sultan Mehmet Training and Research

Hospital, İstanbul Turkey

Cite this article as: Ciyiltepe H, Ergin A, Somay A, Esen Bulut N, Fersahoğlu MM, Köroğlu M, et al. The

Effects of Formalin Solution on Wall Thickness and Size in Stomach Resection Materials. Bosphorus Med J 2021;8(1):41-6.

Received: 07.12.2020 Accepted: 08.01.2021

Correspondence: Dr. Hüseyin Çiyiltepe. Sağlık Bilimleri Üniversitesi, İstanbul Fatih Sultan Mehmet Eğitim ve Araştırma Hastanesi, Genel Cerrahi Kliniği, Istanbul, Turkey

Phone: $-905075830408$

e-mail:

\section{ABSTRACT}

Objectives: Histopathological evaluation of endoscopic submucosal dissection (ESD)/endoscopic full-thickness resection (EFTR) resection materials is important for disease follow-up. There are many studies on the effects of formalin solution on histopathological examination. To our knowledge, in this study, the effects of this solution on the macroscopic dimensions of gastric tissue were investigated for the first time.

Methods: ESD/EFTR specimens were obtained from different localizations of the stomach resection materials removed from patients who underwent laparoscopic sleeve gastrectomy surgery due to morbid obesity. Pre- and post-formalin fixation, macroscopic measurements were made by the surgeon and pathologist conducting the study and compared with each other.

Results: In this study, stomach specimens taken from 50 patients with a mean age of 36.04 , and a body mass index of 46.06 were evaluated. After formalin fixation, it was observed that 4.4, 5.6 and 7.2 times thickening occurred in full-layer wall thicknesses of the antrum, corpus and fundus, respectively. Similarly, 1.8, 2.5 and 4.6 times increase was found in mucosa/submucosa thickness. In addition, due to the shrinkage effect of the formalin solution, an average size reduction of $31.0 \%$ and $23.3 \%$ in the mucosa/submucosa and full-thickness stomach tissue, respectively, were detected.

Conclusion: The shrinkage effect of formalin solution on tissues has been reported before, but it has not provided any evidence of how this effect affects macroscopic measurements. This study is important in that, to our knowledge, it is the first study of formalin fixation to investigate macroscopic size changes on stomach tissue.

Keywords: Formalin fixation; gastric wall thickness; shrinkage.

\section{ÖZET}

Amaç: Endoskopik submukozal rezeksiyon (ESD) veya endoskopik tam kat rezeksiyon (ETR) materyallerinin doğru histopatolojik değerlendirilmesi hastalık takibi açısından oldukça önemlidir. Literatürde formalin solüsyonunun histopatolojik değerlendirme üzerine etkisini araştıran birçok makale bulunmaktadır. Bidiğimiz kadarılya, bu makalede ise ilk kez, bu solüsyonun mide dokusundaki makroskopik ölçümlerine etkisi araştırılmıştır.

Yöntem: Morbid obezite nedeniyle sleeve gastrektomi yapılan hastalardan çıkarılan mide rezeksiyon materyallerinin farklı lokalizasyonlarından ESD/ETR spesmenleri elde edildi. Çalısmayı yürüten cerrah ve patolog tarafından formalin solüsyonu öncesi ve sonrası makroskopik ölçümler yapıldı ve birbiri ile karşılaştıııldı.

Bulgular: Bu çalışmada, ortalama yaşı 36.04 ve vücut kitle indeksi 46.06 olan 50 hastadan alınan mide spesmenleri değerlendirildi. Formalin fiksasyonu sonrası yapılan değerlerdirmede sırasılla antrum, korpus ve fundus tam kat duvar kalınlıklarında 4.4, 5.6 ve 7.2 kat kalınlaşma meydana geldiği izlendi. Benzer şekilde mukoza/submukoza 
kalınlıklarında ise 1.8, 2.5 ve 4.6 kat artış olduğu saptandı. Ayrıca, formalin solüsyonunun meydana getirdiği büzülme etkisi ile mukoza/submukoza ve tam kat mide dokusunda sırasıyla ortalama \%31.0 ve \%23.3 boyut küçülmesi saptandı.

Sonuç: Formalin solüsyonunun dokularda büzülme etkisi olabileceği daha önce literatürde bahsedilmiş olsa da, kanıt düzeyinde makroskopik ölçümlere olan etkisi bildirilmemiştir. Bu çalışma, formalin solüsyonunun mide dokusunda makroskopik boyut değişikliğini bildiren ilk çalışma olması bakımından önemlidir.

Anahtar sözcükler: Büzülme; formalin fiksasyonu; mide duvar kalınlığı.

$\mathrm{E}^{\mathrm{n}}$ ndoscopic mucosal resection (EMR), a part of minimally invasive surgery, was first described in 1974 and has become a commonly performed procedure due to its acceptable oncological results in the treatment of precancerous lesions and early-stage gastric cancers along with its low cost and morbidity rates as has been reported by many studies in the literature. ${ }^{[1-3]}$ Further, the endoscopic submucosal dissection (ESD) technique has been described thanks to the increase in EMR experience and the related developing endoscopy techniques and equipment ${ }^{[4]}$ and it facilitated the resection of larger lesions. Moreover, the endoscopic full-thickness resection (EFTR) technique has also been described for the resection of fibrotic or subepithelial lesions in cases where the EMR/ESD technique was not fitting. [5]

The accurate histopathologic assessment of EMR/ESD/EFTR samples bears critical significance. It not only offers insight into diagnosis and tumor stage but also delivers information about the fittingness of the procedure performed, marginal status and risk factor assessment for nodal metastasis guiding the future treatment and survival of the patients. ${ }^{[6]}$

Many studies have been conducted about the preparation of resected specimens and their transfer to pathology laboratories because the accurate histopathologic evaluation of such samples is technically challenging. However, researchers in these studies have focused on the effects of fixation methods on alterations in histologic features of the specimen rather than the macroscopic alterations in them. ${ }^{[7,8]}$

We, therefore, investigated the effects of $10 \%$ formalin fixation on alterations in specimen sizes of ESD/EFTR samples obtained from gastric specimen resected from patients who underwent laparoscopic sleeve gastrectomy because of morbid obesity.

\section{Methods}

This study was designed prospectively upon the approval of the Board of Ethics at FSMEAH Hospital (No: FSMEAH-
KAEK2018/71, Date: November 08, 2018). In this study, 50 patients who received laparoscopic sleeve gastrectomy because of morbid obesity at our clinic between October and December 2019 were included. Informed consent was obtained from all patients included in this study.

\section{Study Design}

Gastric specimen resected from patients with LSG due to morbid obesity was opened up along the stapler line within the first 30 minutes of the procedure while the gastric mucosa and serosa were evaluated macroscopically by the surgeon conducting the study. Full-thickness gastric tissues of about $6 \mathrm{~cm}^{2}(2 \times 3 \mathrm{~cm})$ in size located in the fundus, corpus and antrum on the greater curvature were resected. The mucosa and submucosa was lifted from the same sites by injecting normal saline under the submucosa. Specimens of similar sizes were obtained through submucosal dissection. The resected specimens were separately fixed by a pin (in the middle of the tissue) on foam specimen containers. In the meantime specimen sizes were measured by a digital vernier caliper and recorded (Fig. 1). The measurement of the material was performed by two different individuals and their average figures were delivered to ensure standardization and the material was fixed in $10 \%$ formalin solution. The material was taken out of the fixation after 12-18 hours

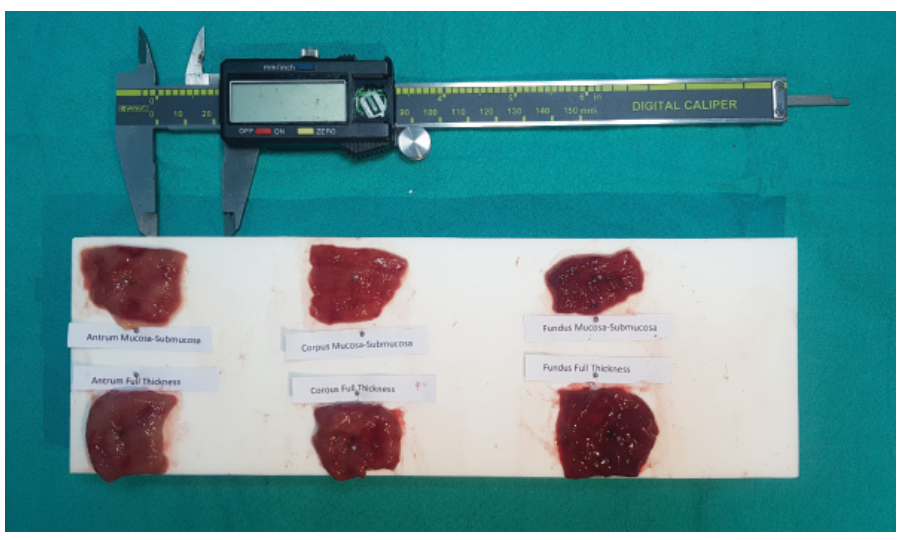

Figure 1. Preparation of ESD/EFTR specimens. 
by the pathologist conducting this study. The same measurements were also recorded by the pathologist without performing any stretching procedure and routine histopathology procedures were performed.

Information on patients' ages, sexes, and body mass indices (BMI) were also recorded within the scope of this study.

\section{Statistical Analysis}

The statistical analyses for this study were performed using the Statistical Package for the Social Sciences (SPSS 21 Inc., Chicago, IL, USA). The recorded data were presented in mean $( \pm \mathrm{SD})$, minimum and maximum figures. The Mann-Whitney U test, Student's t-test, and Wilcoxon signed-rank test were used to compare data on sex and gastric specimen size measurements, while paired samples t-test was utilized to compare fresh tissue and post-formalin fixation measurements. Statistical significance was set at $\mathrm{p}<0.05$.

\section{Results}

This study was conducted with 50 cases, including 16 (32.0\%) male and 34 (68.0\%) female patients, between October and December 2019. While the mean age of the patients was $36.04 \pm 12.68$, their mean BMI was $46.06 \pm 5.57$.

The results of the evaluation revealed that the gastric mucosa-submucosa and full-thickness gastric tissue gradually got thicker from the fundus towards the antrum.

The results of full-thickness gastric tissue and gastric mucosa-submucosa measurements showed that male patients had significantly thicker tissues than female patients, while the difference between the two was reduced as one moved from the fundus towards the antrum (Table 1).

When the patients were divided into two as those over 40 years of age $(n=23)$ and those under $(n=27)$, the resultant evaluation did not reveal any differences between muco-

Table 1. Relationship of stomach wall thickness measurements pre- and post-formalin fixation with gender

\begin{tabular}{|c|c|c|c|c|c|}
\hline & & \multicolumn{2}{|c|}{ Gender } & \multirow[t]{2}{*}{ Total } & \multirow[t]{3}{*}{$\mathrm{p}$} \\
\hline & & Male & Female & & \\
\hline & Fixation & Mead $\pm S D$ & Mead $\pm S D$ & Mead $\pm S D$ & \\
\hline \multirow[t]{3}{*}{ Fundus mucosa+submucosa depth } & Fresh & $0.36 \pm 0.3$ & $0.16 \pm 0.09$ & $0.21 \pm 0.19$ & 1a0.002* \\
\hline & Fixed & $1.03 \pm 0.2$ & $0.95 \pm 0.2$ & $0.97 \pm 0.2$ & \\
\hline & $p^{2 a}$ & $0.002 *$ & $0.000 *$ & $0.000 * 4.6 x$ increase & \\
\hline \multirow[t]{3}{*}{ Fundus Full Thickness Depth } & Fresh & $1.06 \pm 0.66$ & $0.65 \pm 0.27$ & $0.76 \pm 0.45$ & $1 \mathrm{a} 0.010$ * \\
\hline & Fixed & $6.01 \pm 1.62$ & $5.31 \pm 0.88$ & $5.5 \pm 1.16$ & \\
\hline & $\mathrm{p} 2 \mathrm{a}$ & $0.001 *$ & $0.000 *$ & $0.000 *$ & \\
\hline \multicolumn{6}{|l|}{$7.2 \times$ increase } \\
\hline \multirow[t]{3}{*}{ Corpus mucosa+submucosa depth } & Fresh & $0.58 \pm 0.34$ & $0.37 \pm 0.16$ & $0.43 \pm 0.24$ & 1a $0.047 *$ \\
\hline & Fixed & $1.22 \pm 0.21$ & $1.04 \pm 0.17$ & $1.09 \pm 0.2$ & \\
\hline & $\mathrm{p}^{2 \mathrm{a}}$ & $0.001 *$ & $0.000 *$ & $0.000 *$ & \\
\hline \multicolumn{6}{|l|}{$2.5 \mathrm{x}$ increase } \\
\hline \multirow[t]{3}{*}{ Corpus Full Thickness Depth } & Fresh & $1.36 \pm 0.69$ & $0.98 \pm 0.3$ & $1.08 \pm 0.47$ & $1 \mathrm{a} 0.033 *$ \\
\hline & Fixed & $6.1 \pm 1.1$ & $5.99 \pm 1.14$ & $6.02 \pm 1.12$ & \\
\hline & $\mathrm{p}^{2 \mathrm{a}}$ & $0.001 *$ & $0.000 *$ & $0.000 *$ & \\
\hline \multicolumn{6}{|l|}{$5.6 \times$ increase } \\
\hline \multirow[t]{3}{*}{ Antrum mucosa+ submucosa depth } & Fresh & $0.73 \pm 0.35(0.7)$ & $0.62 \pm 0.27(0.5)$ & $0.65 \pm 0.29(0.6)$ & $1 \mathrm{la} 0.179$ \\
\hline & Fixed & $1.26 \pm 0.21(1.2)$ & $1.17 \pm 0.21(1.2)$ & $1.19 \pm 0.21(1.2)$ & \\
\hline & $\mathrm{p}^{2 \mathrm{a}}$ & $0.002 *$ & $0.000 *$ & $0.000 *$ & \\
\hline \multicolumn{6}{|l|}{$1.8 \times$ increase } \\
\hline \multirow[t]{4}{*}{ Antrum Full Thickness Depth } & Fresh & $1.93 \pm 0.94(1.7)$ & $1.23 \pm 0.33(1.2)$ & $1.42 \pm 0.64(1.3)$ & $1 \mathrm{a} 0.001$ * \\
\hline & Fixed & $6.24 \pm 1.53(5.8)$ & $6.29 \pm 1.18(6.3)$ & $6.28 \pm 1.27(6.2)$ & \\
\hline & $p^{2 a}$ & $0.001 *$ & $0.000 *$ & $0.000 *$ & \\
\hline & & & & $4.4 \mathrm{x}$ increase & \\
\hline
\end{tabular}

1aMann-Whitney U test; ${ }^{1 \mathrm{~b}}$ Student t-test; ${ }^{2 a}$ Wilcoxon sign test; ${ }^{2 \mathrm{~b}}$ Paired sample t-test $* \mathrm{p}<0.05$ 
sa-submucosa thickness and full-thickness figures in gastric sections.

When we considered the effects of formalin solution on various anatomical sites of the stomach regardless of age and sex, the following points were observed (Tables 1, 2):

In the fundus site: Gastric mucosa-submucosa was observed to have thickened by 4.6 times, while the full-thickness gastric tissue thickened by 7.2 times in the formalin fixation. Shrinkage was observed in the sizes of gastric mucosa-sub-

Table 2. The assessment of pre- and post-fixation measurements of gastric specimen sizes

\begin{tabular}{|c|c|c|}
\hline & Fixation & $\begin{array}{c}\text { Specimen size }\left(\mathrm{cm}^{2}\right) \\
\text { Mean } \pm S D\end{array}$ \\
\hline \multirow[t]{4}{*}{ Fundus Mucosa+Submucosa } & Fresh & $5.91 \pm 1.0$ \\
\hline & Fixed & $3.82 \pm 0.7$ \\
\hline & $p^{2 b}$ & $0.000 *$ \\
\hline & \% Shrinkage & 35.3 \\
\hline \multirow[t]{4}{*}{ Fundus Full Thickness } & Fresh & $6.34 \pm 1.4$ \\
\hline & Fixed & $4.74 \pm 0.8$ \\
\hline & $p^{2 b}$ & $0.000 *$ \\
\hline & \% Shrinkage & 25.2 \\
\hline \multirow[t]{4}{*}{ Corpus Mucosa+ Submucosa } & Fresh & $6.21 \pm 1.6$ \\
\hline & Fixed & $4.16 \pm 0.9$ \\
\hline & $p^{2 b}$ & $0.000 *$ \\
\hline & $\%$ Shrinkage & 32.9 \\
\hline \multirow[t]{4}{*}{ Corpus Full Thickness } & Fresh & $6.33 \pm 1.3$ \\
\hline & Fixed & $4.86 \pm 0.8$ \\
\hline & $\mathrm{p}^{2 \mathrm{~b}}$ & $0.000 *$ \\
\hline & $\%$ Shrinkage & 23.2 \\
\hline \multirow[t]{4}{*}{ Antrum Mucosa+ Submucosa } & Fresh & $5.47 \pm 1.1$ \\
\hline & Fixed & $3.93 \pm 1.3$ \\
\hline & $p^{2 b}$ & $0.001 *$ \\
\hline & $\%$ Shrinkage & 28.0 \\
\hline \multirow[t]{4}{*}{ Antrum Full Thickness } & Fresh & $5.56 \pm 1.3$ \\
\hline & Fixed & $4.35 \pm 0.8$ \\
\hline & $\mathrm{p}^{2 \mathrm{~b}}$ & $0.002 *$ \\
\hline & $\%$ Shrinkage & 21.7 \\
\hline
\end{tabular}

${ }^{2 b}$ Paired sample t-test $* \mathrm{p}<0.05$

Table 3. Measurement results reported by other studies in literature on gastric wall

\begin{tabular}{|c|c|c|c|c|c|c|c|c|c|c|}
\hline \multirow[b]{2}{*}{ Wall thickness (mm) } & \multicolumn{2}{|c|}{ Elariny ${ }^{10}$} & \multicolumn{2}{|c|}{ Rawlins $^{9}$} & \multicolumn{2}{|c|}{ Van Rutte ${ }^{11}$} & \multicolumn{2}{|c|}{ Susmallian 12} & \multicolumn{2}{|c|}{ Our study } \\
\hline & Female & Male & Female & Male & Female & Male & Female & Male & Female & Male \\
\hline Fundus & 1.61 & 1.81 & 1.94 & 2.09 & 1.37 & 1.37 & 2.58 & 2.66 & 0.65 & 1.06 \\
\hline Corpus & 2.34 & 2.6 & 2.32 & 2.38 & 1.98 & 1.98 & 3.92 & 4.19 & 0.98 & 1.36 \\
\hline Antrum & 3.09 & 3.17 & 2.64 & 2.96 & 2.55 & 2.55 & 5.00 & 5.15 & 1.23 & 1.93 \\
\hline
\end{tabular}

mucosa and the full-thickness gastric tissue $\left(\mathrm{cm}^{2}\right)$ by $35.3 \%$ and $25.2 \%$, respectively, with the fixation in the same site.

In the corpus site: Gastric mucosa-submucosa was observed to have thickened by 2.5 times, while the full-thickness gastric tissue thickened by 5.6 times in the formalin fixation. Shrinkage was observed in the sizes of gastric mucosa-submucosa and the full-thickness gastric tissue $\left(\mathrm{cm}^{2}\right)$ by $32.9 \%$ and $23.2 \%$, respectively, with the fixation in the same site. to have thickened by 1.8 times, while the full-thickness gastric tissue thickened by 4.4 times in the formalin fixation. Shrinkage was observed in the sizes of gastric mucosa-submucosa and the full-thickness gastric tissue $\left(\mathrm{cm}^{2}\right)$ by $28.0 \%$ and $21.7 \%$, respectively, with the fixation in the same site. Pre- and post-formalin fixation measurements were correlated with the above-mentioned results in both sexes.

\section{Discussion}

This study investigated the macroscopic alterations brought about by $10 \%$ formalin solution on ESD/EFTR specimen obtained from the resected stomachs of patients who underwent laparoscopic sleeve gastrectomy. The results of our study revealed that there was on average $32.0 \%$ and $23.3 \%$ shrinkage, respectively, in the sizes of both the mucosa/submucosa and full-thickness gastric tissues and accordingly there was an increase in the thickness of these layers due to this shrinkage. Additionally, our results established that gastric wall thickness increased moving from the fundus towards the antrum and it was thicker in male patients than female similar to those of other studies in the literature ${ }^{[9-12]}$ (Table 3). The impact of BMI on wall thickness could not be investigated since our study group was made entirely of morbidly obese patients (BMI 46.06). However, the same studies $^{\left[{ }^{[9-12]}\right.}$ reported that there was no relationship between gastric wall thickness and BMI, while only Rawlins et al. ${ }^{[9]}$ indicated that the patient group with BMI $>50 \mathrm{~kg} / \mathrm{m}^{2}$ had thicker antrum measurements in comparison to those with lesser BMI. In contradistinction to other studies in litera-
In the antrum site: Gastric mucosa-submucosa was observed 
ture, we were not able to establish any differences between the group over 40 years of age and the group under 40 in terms of gastric wall thickness.

As is presented in Table 3, the measurement results we obtained were lower than those of other studies in the literature. Other researchers plan to compare gastric wall thickness and the type of stapler employed and the effects of these on the results of obesity surgery. They, therefore, performed their measurements on a double layer without opening up a line over a site close to the stapler line. We, on the other hand, carried out the measurements on a single layer over the specimen resected from the side of the greater curvature and we believe that the difference we found could be associated with this fact. In support of our suggestion, Elariny et al. reported in their study ${ }^{[10]}$ that the measurements performed on the side of the greater curvature were thinner in comparison to those performed along the stapler line.

Resections are performed through various endoscopic techniques, which are used in early-stage gastric cancer cases or precancerous gastric lesions, with the gradual spread of minimally invasive methods today and researchers have underlined in comparisons with surgery that similar oncological results were obtained with lower morbidity rates. ${ }^{[2,}$ ${ }^{3]}$ Accurate pathology assessment is a critical component of predicting the long-term results of endoscopic resection in the treatment of these lesions. Many studies have been conducted over the years on the pathology assessment of resected specimen and various techniques have been employed in guidelines as to the ways in which the samples could be fixed and transferred to pathology laboratories. ${ }^{[13]}$

There are two techniques, pinning and direct fixation, in specimen fixing used all around the world. The former is a commonly performed one in Western European and Far Eastern countries during the course of which the resected specimen is fixed on foam with fine pins at frequent intervals and the specimen is evaluated following formalin fixation. ${ }^{[8,14-16]}$ Direct fixation, on the other hand, is a technique used in other countries, particularly in the US, during which the specimen is directly put in formalin solution and evaluated in this way after fixation. ${ }^{[17]}$

The advocates of the pinning technique argue that the specimen edges would shrink due to the muscular layer in the specimen, which, in turn, would affect pathology assessment. The group for the direct fixation technique indicates that fixation with pins brings along over-stretching in the specimen leading to destruction and pin artifacts on the pin entry points which, in turn, affect accurate pathology assessment. ${ }^{[6,15,17]}$

In a study conducted in the Netherlands that investigated the effects of handling methods for EMR specimen in patients with Barrett's esophagus on histopathologic assessment, the authors reported that both the pinning and direct fixation techniques had optimal histopathologic assessment scores (98, 90\%; $p=0.14$, respectively). Authors of the same study also suggested that the direct fixation method should be preferred over pinning on paraffin given the significantly shorter handling time for the preparation of specimen. ${ }^{[13]}$

Pathology studies on gastric tissue in the literature have all reported the shrinkage effect of formalin on tissues but have not offered any evidence on the ways in which this effect was reflected on macroscopic measurements. ${ }^{[14-17]}$ Bejanaro et al. ${ }^{[18]}$ mentioned an estimated $10 \%$ shrinkage due to formalin in esophageal resection material but did not present a definitive value. Siu et al. reported that the effect of formalin fixation on material sizes was 32-39\% in patients who underwent esophagectomy due to esophageal tumors. ${ }^{[19]}$ Further, Goldstein et al. indicated in their study on colon tissue that maximum shrinkage (40\%) occurred as soon as the specimen was resected while shrinkage went up some more after formalin fixation amounting to $57 \%{ }^{[20]}$

\section{Study Limitations}

One of the limitations of this study was that only one method was chosen as the fixation technique, which did not allow for comparisons with other techniques. Another disadvantage was brought about by that the patient population was entirely made up of obese patients, which, in turn, did not allow us to compare their results with those of patients with normal BMI figures.

\section{Conclusion}

This study still proves to be significant since, to our knowledge, it was the first of its kind to investigate the effects of formalin fixation on specimen sizes in ESD/EFTR material obtained from sleeve gastrectomy specimen. It should be remembered that pathology reports present the size of endoscopic resection material as the shrunk version of their macroscopic sizes. We believe that additional reporting of fresh tissue sizes in pathology reports would bear significance for further clinical studies. 


\section{Disclosures}

Ethics Committee Approval: This study was designed prospectively upon the approval of the Board of Ethics at FSMEAH Hospital (No: FSMEAH-KAEK2018/71, Date: November 08, 2018).

Peer-review: Externally peer-reviewed.

Conflict of Interest: None declared.

Authorship Contributions: Concept - H.Ç., Ü.A., A.B.K.; Design - H.Ç., Ü.A., K.M.; Supervision - Ü.A., K.M.; Materials - M.M.F., N.E.B., M.K., A.E.; Data collection \&/or processing - A.S., H.Ç., A.E.; Analysis and/or interpretation - H.Ç., A.B.K., A.S.; Literature search - H.Ç., A.B.K., A.S.; Writing - H.Ç.; Critical review - A.B.K., Ü.A., K.M.

\section{References}

1. Ko WJ., Song GW., Kim WH., Hong SP., Cho JY. Endoscopic resection of early gastric cancer: current status and new approaches. Translational gastroenterology and hepatology, 2016;1:24,9-18

2. An L., Gaowa S., Cheng H., Hou M. Long-term outcomes comparison of endoscopic resection with gastrectomy for treatment of early gastric cancer: A systematic review and meta-analysis. Frontiers in oncology, 2019; 9; 725, 1-10

3. Pyo JH., Lee H., Min BH., Lee JH., Choi MG., Lee JH., et al. Longterm outcome of endoscopic resection vs. surgery for early gastric cancer: a non-inferiority-matched cohort study. The American journal of gastroenterology, 2016;111(2), 240, 1-10

4. Nakamoto S., Sakai Y., Kasanuki J., Kondo F., Ooka Y., Kato K., et al. Indications for the use of endoscopic mucosal resection for early gastric cancer in Japan: a comparative study with endoscopic submucosal dissection. Endoscopy, 2009; 41(09), 746-50.

5. Fazlollahi L., Remotti HE. Pathology perspective on endoscopic full thickness resection (EFTR) Tech Gastrointest Endosc, 2019; 21,7-12

6. Sun Q. Huang Q. Pathologic Evaluation of Endoscopic Resection Specimens. In Gastric Cardiac Cancer, Springer, Cham. 2018; 227-41

7. Mitsuhashi T., Lauwers GY., Ban S., Mino-Kenudson M., ShimizuY., Ogawa F., et al. Post-gastric endoscopic mucosal resection surveillance biopsies: evaluation of mucosal changes and recognition of potential mimics of residual adenocarcinoma. The American journal of surgical pathology, 2006; 30(5), 650-56.

8. Geramizadeh B., Owen DA. Handling and pathology reporting of gastrointestinal endoscopic mucosal resection. Middle East journal of digestive diseases, 2017; 9(1), 5.
9. Rawlins L., Rawlins MP., Teel D. Human tissue thickness measurements from excised sleeve gastrectomy specimens. Surgical endoscopy, 2014;28(3), 811-4

10. Elariny H, Gonzalez H, Wang B. Tissue thickness of human stomach measured on excised gastric specimens from obese patients. Surg Technol Int 2005; 14: 119-24.

11. Van Rutte PW, Naagen BJ, Spek M, Jakimowicz JJ, Nienhuijs SW. Gastric wall thickness in sleeve gastrectomy patients: thickness variation of the gastric wall. Surg Technol Int 2015; 27: 123-8.

12. Susmallian S., Goitein D., Barnea R., Raziel A. Correct Evaluation of Gastric Wall Thickness May Support a Change in Staplers' Size When Performing Sleeve Gastrectomy. The Israel Medical Association journal,IMAJ, 2017;19(6), 351-4.

13. Overwater A., van der Meulen KE., KünzliHT., Schoon EJ., Bergman JJ., Raicu GM., et al. Optimizing histopathologic evaluation of EMR specimens of Barrett's esophagus-related neoplasia: a randomized study of 3 specimen handling methods. Gastrointest Endosc 2019;90:384-92

14. Lauwers GY., Ban S., Mino M., Ota S., Matsumoto T., Arai S., et al. Endoscopic mucosal resection for gastric epithelial neoplasms: a study of 39 cases with emphasis on the evaluation of specimens and recommendations for optimal pathologic analysis. Modern pathology, 2014; 17(1), 2.

15. Mojtahed A., Shimoda T. Proper pathologic preparation and assessment of endoscopic mucosal resection and endoscopic submucosal dissection specimens. Techniques in Gastrointestinal Endoscopy, 2011; 13(1), 95-9.

16. Stolte M., Dostler I.Good handling and pathological examination of endoscopic resections of early Barrett's cancer. Diagnostic Histopathology, 2012; 18(12), 498-502.

17. Greene CL., Worrell SG., Attwood SE., Chandrasoma P., Chang K., DeMeester TR., et al. Emerging concepts for the endoscopic management of superficial esophageal adenocarcinoma. Journal of Gastrointestinal Surgery, 2016; 20(4), 851-60.

18. Bejarano PA., Berho M. Examination of surgical specimens of the esophagus. Archives of pathology\&laboratory medicine, 2015; 139(11), 1446-54.

19. Siu KF., Cheung HC., Wong J. Shrinkage of the esophagus after resection for carcinoma. Annals of surgery, 1986; 203(2), 173.

20. Goldstein NS., Soman A., Sacksner J. Disparate surgical magrin lengths of colorectal resection specimens between in vivo and in vitro measurements: the effects of surgical resection and formalin fixation on organ shrinkage. American journal of clinical pathology, 1999; 111(3), 349-51. 